\title{
PENDEKATAN EKSPLORASI UNTUK MENGEMBANGKAN KEMAMPUAN SELF-REGULATED LEARNING (SRL) MATEMATIKA SISWA SMP
}

\author{
Dhia Octariani ${ }^{1}$, Isnaini Halimah Rambe ${ }^{2}$ \\ ${ }^{1,2}$ Universitas Islam Sumatera Utara \\ dhia88octariani@gmail.com, isnainirambey89@gmail.com
}

\begin{abstract}
This research is an experimental study with only posttest control design that aims to develop students' mathematical self-regulated learning (SRL) abilities. The population subject is VII grade private junior high school students in one of the schools in Medan. The experimental class gets learning with an exploratory approach and the control class gets conventional learning. With a total number of students 68 students of class VII junior high school consisting of 34 students in the experimental class, and 34 students in the control class. The instruments used in this study were mathematics self-regulated learning (SRL) scale, observation sheets, and questionnaire results. The results of this study indicate that an exploratory approach can improve the ability of mathematical self-regulated learning (SRL) better than using conventional approaches.
\end{abstract}

Keyword: Learning, Exploration Learning, Self-Regulated Learning (SLR)

\begin{abstract}
Abstrak
Penelitian ini merupakan penelitian eksperimen dengan disain kontrol hanya postes yang bertujuan untuk mengembangkan kemampuan self-regulated learning (SRL) matematika siswa. Subjek populasinya adalah siswa SMP Swasta kelas VII di salah satu sekolah di Kota Medan. Kelas eksperimen mendapat pembelajaran dengan pendekatan eksplorasi dan kelas kontrol mendapat pembelajaran konvesional. Dengan total jumlah siswa 68 siswa SMP kelas VII yang terdiri dari 34 siswa pada kelas eksperimen, dan 34 siswa pada kelas kontrol. Instrumen yang digunakan dalam penelitian ini yaitu skala self-regulated learning (SRL) matematika, lembar observasi, dan hasil angket. Hasil dari penelitian ini menunjukkan bahwa pendekatan eksplorasi dapat meningkatkan kemampuan self-regulated learning (SRL) matematika lebih baik dibandingkan menggunakan pendekatan konvensional.
\end{abstract}

Kata Kunci: Pembelajaran, Pendekatan Eksplorasi, Self-Regulated Learning (SLR)

\section{Pendahuluan}

Permendiknas Nomor 22 Tahun 2006 mendefinisikan matematika merupakan salah satu pelajaran yang bertujuan untuk mendidik siswa mampu berfikir logis, analitis, sistematis, kritis, dan kreatif serta kemampuan bekerja sama. Sesuai dengan tujuan diberikannya matematika di sekolah, dapat dilihat bahwa matematika memegang peranan yang sangat penting. Sampai saat ini kebanyakan siswa masih menganggap matematika sebagai pelajaran yang sulit dan membosankan.

Menurut Soedjadi (dalam Siswono, 2011) kemampuan yang dapat diperoleh dalam pembelajaran matematika diantaranya adalah kemampuan berpikir kreatif, kemampuan berpikir dan 
bertindak secara mandiri berdasarkan alasan yang dapat dipertanggungjawabkan, serta kemampuan memecahkan masalah dalam berbagai situasi. Dari pendapat tersebut jelas terlihat bahwa dalam pembelajaran matematika memerlukan kemandirian belajar atau disebut juga self-regulated learning (SRL). Dari SRL tersebut kemudian akan tercipta kepercayaan diri pada siswa. Serta kemampuan berpikir kreatif menjadi salah satu kemampuan berpikir tingkat tinggi yang harus dikembangkan dalam diri siswa.

Hal ini sesuai dengan apa yang dijelaskan dalam peraturan pemerintah No.19 tahun 2005 tentang Standar Nasional pendidikan bab V pasal 26 bahwa standar kompetensi lulusan pada jenjang pendidikan dasar bertujuan untuk meletakkan dasar kecerdasan, pengetahuan, kepribadian, akhlak mulia, serta keterampilan untuk hidup mandiri dan mengikuti pendidikan yang lebih tinggi. Dari uraian tersebut dapat jelas terlihat bahwa pembelajaran yang dilaksanakan di kelas bertujuan agar siswa mampu mandiri. Self-regulated learning (SRL) dikonsepkan sebagai usaha membangkitkan metakognitif, motivasi, dan perilaku siswa yang aktif berpartisipasi dalam proses belajar mereka sendiri untuk meningkatkan prestasi akademik.

Menurut Rohaeti, Budiyanto, dan Sumarmo (2014), self-regulated learning (SRL) penting dalam mengevaluasi dan mengelola pembelajaran secara efektif. Siswa yang mempunyai SRL tinggi akan mampu membagi waktu secara efisien sehingga mereka mampu menyelesaikan permasalahan matematis secara mandiri, dan memperoleh hasil belajar matematika karakteriktik utama yang termuat dalam SRL yaitu (1) individu merancang belajarnya sendiri sesuai dengan keperluan atau tujuan belajar individu yang bersangkutan; (2) individu memilih strategi dan melaksanakan rancangan belajarnya; (3) individu memantau kemajuan belajarnya sendiri, mengevaluasi hasil belajarnya dan dibandingkan dengan standar tertentuyang lebih baik.

Sumarmo, (2004) mengutarakan tentang indikator dalam SRL, yaitu:

1. Inisiatif belajar;

2. Mendiagnosa kebutuhan belajar;

3. Menetapkan target dan tujuan belajar;

4. Memonititor, mengatur, dan mengontrol;

5. Memandang kesulitan sebagai tantangan;

6. Memanfaatkan dan mencari sumber yang relevan;

7. Memilih dan menetapakan sumber belajar;

8. Mengevaluasi proses dan hasil belajar;

9. Konsep diri.

Untuk mengembangkan kemampuan self-regulated learning (SRL) secara optimal, dalam tulisan ini penulis mencoba menawarkan pendekatan eksplorasi. Pendekatan eksplorasi merupakan suatu pendekatan yang bertujuan untuk membimbing siswa menemukan suatu konsep atau 
memecahkan suatu permasalahan sehingga dapat memberikan kesempatan kepada siswa tersebut untuk berinovasi dengan ide-ide dan cara-cara yang berbeda. Di dalam pendekatan ini guru membimbing siswa mengkonstruksi pengetahuannya secara aktif melalui sejumlah pertanyaanpertanyaan dan perintah-perintah. Siswa juga didorong untuk menyusun, mengevaluasi dan mengaplikasikan konsep matematika serta mengetahui sifat-sifat dan hubungan antar konsep tersebut untuk menarik kesimpulan logis. Eksplorasi melalui sejumlah pertanyaan dan perintah juga diharapkan dapat memunculkan banyak gagasan dari para siswa, kemudian para siswa dapat mencari kombinasi terbaik dari gagasan tersebut dan pada akhirnya dapat memutuskan mana kombinasi terbaik untuk melakukan suatu tindakan.

Adapun Rohmat (2014: 18) mengungkapkan peran guru dalam pendekatan eksplorasi, diantaranya: 1) Melibatkan siswa mencari informasi yang luas dan dalam tentang topik/tema materi yang akan dipelajari serta belajar dari aneka sumber, 2) Guru harus menggunakan beragam pendekatan pembelajaran, media pembelajaran dan sumber belajar lainnya, 3) Memfasilitasi terjadinya interaksi antar siswa dengan siswa, siswa dengan guru, lingkungan, dan sumber belajar lainnya, 4) Melibatkan peserta didik secara aktif dalam setiap kegiatan pembelajaran, 5) Memfasilitasi peserta didik melakukan percobaan di laboratorium, studio, atau lapangan.

Pendekatan eksplorasi merupakan salah satu pendekatan yang berlandaskan pada teori kontruktivisme. Teori kontruktivisme merupakan teori yang mendukung pelaksanaan kegiatan pembelajaran yang berpusat pada siswa. Pendekatan eksplorasi merupakan suatu pendekatan yang bertujuan untuk menggali ide-ide, argumen-argumen dan cara-cara yang berbeda dari siswa melalui sejumlah pertanyaan-pertanyaan terbuka dan perintah-perintah sehingga dapat mengantarkan siswa tersebut kepada pemahaman suatu konsep serta penyelesaian masalah-masalah. Dalam pendekatan ini siswa menjadi penjelajah aktif (active explorer) dan guru hanya berperan sebagai pembimbing dan fasilitator eksplorasi tersebut. Tahap - tahap dalam pendekatan eksplorasi yaitu :

a. Tahap Persiapan

Pada tahap ini guru memberi pertanyaan-pertanyaan terbuka untuk menggali pengetahuan awal siswa, mendiagnosis dan memperbaiki kelemahan penguasaan konsep yang telah diperoleh siswa yang berhubungan dengan konsep baru yang akan dipelajarinya.

b. Eksplorasi Penemuan Konsep Baru

Pada tahap ini siswa diberi kesempatan untuk mengemukakan ide-ide dan cara-cara yang berbeda dan mengemukakan argumen atas ide-ide dan cara-cara yang dikemukakannya. Konsep baru yang ditemukannya kemudian dikomunikasikan dengan bahasanya sendiri.

c. Eksplorasi Aplikasi Konsep baru

Pada tahap ini siswa diberikan kesempatan untuk mengemukakan ide-ide dan cara-cara yang berbeda dalam menyelesaikan masalah tersebut. Siswa pun dituntut untuk memberikan argumen atas ide dan cara-cara yang dikemukakannya. 
Pada ketiga tahap eksplorasi tersebut, guru memfasilitasi terjadinya tukar pendapat, tukar ide, dan tukar cara-cara antar siswa melalui diskusi kelas. Guru membimbing siswa sehingga para siswa akhirnya dapat mengambil kesimpulan dari berbagai ide dan cara yang dikemukakannya.

Berdasarkan seluruh uraian yang dikemukakan di atas, penulis meneliti penggunaan pembelajaran dengan pendekatan eksplorasi dalam upaya mengembangkan kemampuan self-regulated learning (SRL) matematika siswa Sekolah Menengah Pertama (SMP).

\section{Metode}

Rancangan penelitian yang digunakan dalam penelitian ini adalah The Matching Only Post Test Only Control Group Design (Sugiyono, 2007). Struktur desainnya dapat di lihat pada Tabel dibawah ini:

Tabel 1. Rancangan Penelitian Eksperimental Desain penelitian ini the matching only postest control group design

\begin{tabular}{|c|c|c|}
\hline Kelas & Perlakuan & Nilai Hasil Post Test \\
\hline Kelas Eksperimen & $\mathrm{X}_{1}$ & $\mathrm{~T}_{2}$ \\
\hline Kelas Kontrol & $\mathrm{X}_{2}$ & $\mathrm{~T}_{2}$ \\
\hline
\end{tabular}

Ket :

$\mathrm{X}_{1}=$ Perlakuan dengan menggunakan pendekatan eksplorasi

$\mathrm{X}_{2}=$ Perlakuan dengan menggunakan pembelajaran konvensional

$\mathrm{T}=$ Tes akhir (posttest) skala SRL siswa

Yang menjadi subjek populasi dalam penelitian ini adalah seluruh siswa SMP Swasta kelas VII di salah satu sekolah di Kota Medan. Seluruh siswa kelas VII di sekolah tersebut ditetapkan sebagai populasi dengan alasan tingkat perkembangan kognitif siswa berada pada tahap peralihan dari operasi konkrit ke operasi formal. Menurut teori Piaget, siswa SMP kelas VII sudah mulai memasuki tahap berpikir formal. Oleh karena itu, pada siswa SMP kelas VII ini sudah mulai dikenalkan dengan materimateri yang bersifat abstrak.

Pemilihan sampel dengan purposive sampling dengan tujuan penelitian dapat berlangsung secara tepat, efektif, dan efisien dalam hal pelaksanaan, waktu, tempat penelitian, dan administrasi. Dua kelompok yang dipilih sebagai sebagai sampel penelitian adalah kelompok eksperimen siswa kelas VIIA sebanyak 34 siswa yang menggunakan pembelajaran dengan pendekatan eksplorasi dan kelompok kontrol siswa kelas VIIB sebanyak 34 siswa dengan pembelajaran strategi konvensional. 
Pengumpulan data dilakukan melalui skala SRL, lembar observasi, dan hasil angket. Skala SRL diberikan sesudah proses pembelajaran dalam penelitian, lembar observasi diberikan pada saat pembelajaran berlangsung, angket diberikan sesudah pembelajaran berlangsung. Analisis data skala SRL dapat dilakukan dengan cara menentukan persentase jawaban siswa untuk masing-masing pernyataan yang selanjutnya dianalisis dengan skala Likert. Selanjutnya, data kualitatif diperoleh dari analisis lembar observasi, wawancara. Analisis lembar observasi yaitu data ditulis dan dikumpulkan berdasarkan permasalahan, selanjutnya dianalisis secara deskriptif. Hasil observasi diolah secara deskriptif dan hasilnya dianalisis melalui laporan penulisan essay yang menyimpulkan kriteria, karakteristik serta proses yang terjadi dalam pembelajaran. Analisis pedoman angket diolah dan dianalisis secara deskriptif setelah terjadi pembelajaran.

\section{Hasil dan Pembahasan}

Data self-regulated learning (SRL) siswa diperoleh melalui pemberian skala SRL pada akhir pembelajaran (posttest). Berdasarkan hasil posttest, maka dianalisis dengan pemberian skor menggunakan penskoran skala Likert. Rata-rata SRL yang diperoleh dari perhitungan dengan menggunakan SPSS V.20 for windows yang merupakan gambaran SRL siswa yang memperoleh pembelajaran dengan pendekatan eksplorasi dan yang memperoleh pembelajaran konvensional. Berikut merupakan deskriptif data hasil SRL siswa kelas eksperimen dan kelas kontrol yang disajikan pada tabel berikut ini:

Tabel 2. Skor Statistik Deskriptif Skala SKL Siswa

\begin{tabular}{|l|c|c|c|c|}
\hline \multicolumn{1}{|c|}{ Kelas } & $\begin{array}{c}\text { Skor } \\
\text { Ideal }\end{array}$ & \multicolumn{3}{|c|}{ Post test } \\
\hline & & $\bar{x}$ & $x_{\text {maks }}$ & $x_{\min }$ \\
\hline Eksperimen (Eksplorasi) & 100 & 84,64 & 92 & 76 \\
\hline Kontrol (Konvensional) & 100 & 74,78 & 89 & 70 \\
\hline
\end{tabular}

Berdasarkan hasil di atas, terlihat bahwa skor maksimum untuk kelas eksperimen adalah 92 dan terendah 76 sedangkan untuk kelas kontrol skor tertinggi 89 dan terendah 70 . Terlihat juga bahwa rerata skor kelas eksperimen lebih tinggi dari kelas kontrol, Uji perbedaan rerata skor SRL siswa untuk mengetahui perbedaan pencapaian SRL siswa kelas eksperimen dengan siswa kelas kontrol. Berdasarkan hasil perhitungan uji beda rata-rata nilai posttest kedua kelas menggunakan uji-U (MannWhitney) didapatkan bahwa rata-rata posttest kelas eksperimen berbeda dengan rata-rata posttest kelas kontrol. Dapat disimpulkan pula bahwa kemampuan self-regulated learning siswa dengan pendekatan eksploratif meningkat lebih baik dibandingkan dengan siswa yang mengalami pembelajaran konvensional. 
Berdasarkan hasil observasi hampir seluruh siswa memiliki self-regulated learning (SRL) dalam matematika. Terutama dalam kelas eksperimen dengan pendektan eksplorasi, mampu mngembangkan self-regulated learning (SRL) matematika lebih baik dari pembelaran konvensional yang berlangsung pada kelas kontrol. Hasil angket yang didapat di akhir pembelajran menyatakan bahwa hampir seluruh siswa sangat senang dengan pembelajaran pada setiap pertemuan sehingga siswa bisa memahami materi yang disampaikan dengan baik sehingga hasil belajar yang dicapai lebih baik.

Sejalan dengan itu, Aini \& Taman (2017) menyatakan bahwa prestasi belajar dan SRL (kemandirian belajar) saling mempengaruhi. Menurut Aini \& Taman (2012), prestasi belajar yang baik dalam pelajaran, maka pencapaian SRL juga baik. Pengembangan SRL siswa bisa dilakukan apabila siswa masih menduduki tingkat Sekolah Menengah Pertama (SMP).

Berdasarkan perhitungan statistik dengan kriteria pengujian adalah tolak $\mathrm{H}_{0}$ jika sig $\leq \alpha$, dan terima $\mathrm{H}_{0}$ jika sig $>\alpha$ dengan $\alpha=0,05$. Jika $\mathrm{H}_{0}$ di tolak, berarti Ha diterima yang artinya rata-rata kemampuan self-regulated learning matematika siswa yang menggunakan pembelajaran dengan pendekatan eksplorasi lebih tinggi dari rata-rata kemampuan self-regulated matematika siswa yang menggunakan model pembelajaran konvensional pada siswa SMP kelas VII.

Hipotesis yang akan diuji adalah: "terdapat perbedaan pencapaian self-regulated learning secara signifikan antara siswa yang memperoleh pembelajaran dengan pendektan eksplorasi dengan siswa yang memperoleh pembelajaran konvensional". Hipotesis statistiknya adalah:

$$
\begin{aligned}
H_{0}: \mu_{1}=\mu_{2} & : \text { Rerata akhir SRL siswa kelas eksperimen tidak berbeda secara signifikan } \\
& \text { dengan rerata akhir SRL siswa kelas kontrol. } \\
H_{a}: \mu_{1} \neq \mu_{2}: & \text { Rerata akhir SRL matematika siswa kelas eksperimen berbeda secara signifikan } \\
& \text { dengan rerata akhir SRL siswa kelas kontrol. }
\end{aligned}
$$

Keterangan:

$\mu_{1}:$ rerata akhir SRL siswa kelas eksperimen.

$\mu_{2}:$ rerata peringkat akhir SRL siswa kelas kontrol

Tabel 3. Hasil Uji Perbedaan Rerata Data SRL Siswa

\begin{tabular}{|l|c|c|}
\hline & SRL & Kesimpulan \\
\hline Uji-U (Mann-Whitney U) & 78,000 & \\
\hline Z & $-6,825$ & \multirow{2}{*}{$\mathrm{H}_{0}$ ditolak } \\
\hline Asymp. Sig. (2-tailed) & 000 & \\
\hline
\end{tabular}


Dari table diatas terdapat perbedaan antara rerata peringkat akhir SRL siswa yang memperoleh pembelajaran dengan pendekatan eksplorasi dan siswa yang memperoleh pembelajaran konvensional.

Hasil presentasi SRL secara keseluruhan untuk indikator 1 sampai 9 adalah nilai rerata SRL siswa pada kelas eksperimen lebih tinggi dari kelas kontrol, yaitu 52,12\% untuk kelas eksperimen dan $42,31 \%$ untuk kelas kontrol.

Gambaran kinerja siswa selama proses pembelajaran dengan pendekatan eksplorasi yaitu pada pertemuan pertama dan kedua siswa merasa tidak familiar dengan eksplorasi dan inovasi. Tahap ini menurut Shihu dan Jijian (2001) disebut dengan tahap mendidik. Pada pertemuan ketiga siswa pada kelas eksperimen mulai terbiasa menggali sendiri pengetahuannya, dan mulai tidak takut untuk berbeda dengan teman-temannya. Siswa-siswa yang asalnya selalu diam mulai berani mengemukakan pendapatnya secara lisan dan menuliskan hasil pemecahan masalah di papan tulis. Sedangkan untuk siswa dari kelas kontrol tahap ini baru berjalan efektif pada pertemuan keempat. Tahap ini disebut dengan tahap embrionik dimana siswa mulai kreatif menyatakan hasil eksplorasinya. Pada pertemuan keempat untuk siswa kelas eksperimen dan pertemuan kelima untuk siswa dari kelas kontrol para siswa sudah mulai lancar mengemukakan ide-idenya dan mengungkapkan konsep dengan bahasanya sendiri. Tahap ini disebut dengan tahap mencoba, dimana siswa mulai membuat pemahaman pengetahuan dan mencobanya.Pada saat eksplorasi kelompok, karena mereka sudah terbiasa dengan ide-ide yang berbeda, komunikasi antar anggota kelompok terlihat lebih ramai dan komunikatif. Masing-masing anggota tidak takut lagi mengemukakan idenya dan siswa yang lain pun saling memberi masukan dan ide untuk memperoleh jawaban yang diinginkan. Tahap ini disebut dengan tahap pertumbuhan, dimana siswa terbiasa berinovasi dan telah mampu bereksplorasi.

Berdasarkan pembahasan di atas serta hasil analisis data yang penulis uraikan, maka penulis menyimpulkan bahwa ada peningkatan pembelajaran dengan pendekatan eksplorasi terhadap kemampuan self-regulated learning matematika siswa kelas VII.

\section{Kesimpulan}

Berdasarkan hasil analisis penelitian yang telah dilakukan, penulis dapat menyimpulkan bahwa pembelajaran dengan pendekatan eksplorasi mampu mengembangkan dan meningkatkan selfregulated learning (SRL) siswa SMP kelas VIIA lebih baik dibandingkan pembelajaran dengan konvensional di kelas VIIB. Pembelajaran dengan pendekatan eksplorasi tidak hanya meningkatkan self-regulated learning (SRL) tetapi juga mampu menumbuhan percaya diri siswa serta menumbuhkan minat belajar siswa. 


\section{Referensi}

Aini, P. N. \& Taman, A. (2012). Pengaruh kemandirian belajar dan lingkungan belajar siswa terhadap prestasi belajar akuntansi siswa kelas XI IPS SMAN 1 Sewon Bantul tahun ajaran 2010/2011. Jurnal Pendidikan Akuntansi Indonesia, X (1), hlm. 48-65.

Azwar, S. (2007). Penyusunan Skala Psikologi. Yogyakarta: Pustaka Pelajar

Depdiknas . (2006). Permendiknas No 22 Tahun 2006 Tentang Standar Isi. Jakarta : Depdiknas.

Rohmat, I. (2014). Penerapan Pembelajaran Eksploratif untuk Meningkatkan Kemampuan Pemahaman dan Komunikasi Matematis Siswa SMP. Tesis UPI Bandung: Tidak diterbitlkan.

Rohaeti, E. E., Budiyanto, A.M., \& Sumarmo, U. (2014). Enhancing students' mathematical logical thinking ability and self regulated learning through problem based learning. International Journal of Education, 8 (1), 53-63.

Shihu, L. \& Jijian, W. (2001). Eksperimen Study on Mathematics Exploration Teaching in Secondary School. Lanzhou: Educaion College, Northwest Normal University

Siswono, T. (2011). "Membangun karakter melalui pembelajaran matematika" makalah pada seminar Nasional Pendidikan Matematika. Universitas Lambung Mangkurat, Banjarmasin.

Sugiyono. (2007). Metode Penelitian Kuantitatif Kualitatif dan R\&D. Bandung: Alfabeta.

Sumarmo, U. (2004). Kemandirian Belajar : Apa, Mengapa, dan Bagaimana Dikembangkan pada Peserta Didik. Laporan Penelitian Hibah Pascasarjana UPI. Bandung : Tidak dipublikasikan. 